\title{
NuRSES' PERCEPTIONS ABOUT BOTSWANA PATIENTS' ANTI-RETROVIRAL THERAPY ADHERENCE
}

\section{Authors:}

Esther Kip

Valerie J. Ehlers ${ }^{1}$

Dirk M. van der Wal ${ }^{1}$

\section{Affiliations:}

${ }^{1}$ Department of Health Studies, University of South Africa, South Africa

\section{Correspondence to:} Valerie J. Ehlers

e-mail:

ehlervj@unisa.ac.za

Postal address: PO Box 392, UNISA 0003, South Africa

\section{Keywords:}

HIV nursing; ARVs (anti-retrovirals); ART (anti-retroviral therapy) adherence; Botswana; HIV/AIDS

Dates:

Received: 04 Sep. 2008 Accepted: 01 June 2009 Published: 03 Aug. 2009

How to cite this article: Kip, E., Ehlers, V.J. \& Van der Wal, D.M., 2009 'Nurses' perceptions about Botswana patients' anti-retroviral therapy adherence', Health SA Gesondheid 14(1), Art. \#466, 8 pages. DOI: $10.4102 /$ hsag.v14i1.466

This article is available

http://www.hsag.co.za
(C) 2009. The Authors. Licensee: OpenJournals Publishing. This work is licensed under the Creative Commons Attribution License.

\section{ABSTRACT}

Anti-retroviral drugs (ARVs) are supplied free of charge in Botswana. Lifelong adherence to antiretroviral therapy (ART) is vital to improve the patient's state of well-being and to prevent the development of strains of the human immunodeficiency virus (HIV) that are resistant to ART. Persons with ART-resistant strains of HIV can spread these to other people, requiring more expensive ART with more severe side-effects and poorer health outcomes. The purpose of this exploratory, descriptive, qualitative study was to determine nurses' perspectives on Botswana patients' anti-retroviral therapy (ART) adherence, and to identify factors which could promote or hinder ART adherence. Four ART sites were randomly selected and all 16 nurses providing ART services at these sites participated in semi-structured interviews. These nurses indicated that patients' ART adherence was influenced by service-related and patient-related factors. Servicerelated factors included the inaccessibility of ART clinics, limited clinic hours, health workers' inability to communicate in patients' local languages, long waiting times at clinics and delays in being informed about their CD4 and viral load results. Nurses could not trace defaulters nor contact them by phone, and also had to work night shifts, disrupting nurse-patient relationships. Patient-related factors included patients' lack of education, inability to understand the significance of CD4 and viral load results, financial hardships, non-disclosure and non-acceptance of their HIV positive status, alcohol abuse, the utilisation of traditional medicines and side effects of ART. The challenges of lifelong ART adherence are multifaceted involving both patient-related and servicerelated factors. Supplying free ARVs does not ensure high levels of ART adherence.

\section{OPSOMMING}

Anti-retrovirale middels (ARMs) word gratis verskaf in Botswana. Lewenslange getroue nakoming van ARM voorskrifte is noodsaaklik om die pasiënt se algehele staat van welsyn te verbeter en om die ontwikkeling te voorkom van stamme van die menslike immuun-gebrek virus (MIV) wat weerstand bied teen anti-retrovirale behandeling (ARB). Persone met ARB-weerstandbiedende MIV stamme kan dit versprei na ander mense toe, wat duurder ARB vereis met swakker gesondheidsuitkomste. Die doel van hierdie verkennende, beskrywende, kwalitatiewe studie was om te bepaal wat verpleegkundiges se sienings is oor pasiënte in Botswana se nakoming van $A R B$, en om faktore te identifiseer wat die ARB-nakoming kan bevorder of benadeel. Vier ARB terreine was ewekansig gekies en al 16 verpleegkundiges wat ARB dienste by die terreine verskaf, het deelgeneem aan semi-gestruktureerde onderhoude. Hierdie verleegkundiges het aangedui dat pasiënte se ARB handhawing beïnvloed word deur diens-verwante en pasiëntverwante faktore. Diens-verwante faktore behels die ontoeganklikheid van ARB klinieke, beperkte kliniekure, gesondheidswerkers se onvermoë om in pasiënte se plaaslike tale te kommunikeer, lang wagtye by klinieke en vertragings om ingelig te word oor uitslae van CD4 en virale tellings. Verpleegkundiges kan nie pasiënte opvolg of telefonies kontak wat versuim om op te daag vir behandeling nie. Verpleegkundiges moet nagskofte werk wat pasiënt-verpleegkundige verhoudings onderbreek. Pasiënt-verwante faktore behels pasiënte se gebrekkige opvoeding, hulle onvermoë om die belangrikheid van uitslae van CD4 en virale tellings te verstaan, finansiële ontberinge, nie-openbaarmaking en nie-aanvaarding van hulle MIV positiewe status, alkohol misbruik, die gebruik van tradisionele medisynes en die newe-effekte van ARB. Die uitdagings van lewenslange ARB handhawing is veelsydig en behels beide pasiënt-verwante en diens-verwante faktore. Die verskaffing van gratis ARMs verseker nie ARB handhawing nie.

\section{INTRODUCTION AND BACKGROUND INFORMATION}

Botswana is a middle-income country in southern Africa with a gross domestic product of US\$3 300 and a sustained growth rate of $9.0 \%$ per annum (UNAIDS 2004:1). However, Botswana faces three major developmental challenges, namely HIV/AIDS, poverty and environmental degradation. The 2003 national HIV prevalence rate was reported to be $17.3 \%$, but $37.4 \%$ among pregnant women aged $15-49$ who attended ante-natal clinics. At the end of 2002, an estimated 330000 people lived with HIV / AIDS in Botswana, based on the established prevalence rate among pregnant women (UNAIDS 2004:1). If 30\% of the estimated 330000 people living with HIV / AIDS in Botswna required ART, the demand for ART has been estimated to be 110000 people in 2001 (De Korte, Mazonde \& Darkoh 2004:2). Botswana is one of the first countries in Africa to provide ART to its citizens free of charge (NACA \& CSO 2004:4).

Grubb, Perriens and Schwartlander (2003:3) maintain that the introduction of ART needs a well functioning health system with adequately trained health professionals, laboratory support, constant supplies of drugs and social systems to assist patients' adherence and prevent future treatment failures. Reliable laboratory support to diagnose HIV and common opportunistic infections, to determine biological eligibility for anti-retroviral drugs (ARVs) and to monitor side effects should be available at any facility providing ART (Stewart, Paradath \& Bamford 2004:1). An effective drug regulatory authority is required to ensure safety, efficacy and quality of all drugs by monitoring quality assurance and regular distribution. Monitoring and evaluating the broader impact of HIV / AIDS treatment is vitally important to the success of ARV programmes (WHO 2003). In Botswana, the challenges prior to the implementation 
of the nationwide ART programme included lack of monitoring and evaluation expertise as well as a reliance on paper-based data management and record keeping systems. Patients' ART adherence could be enhanced when health care workers provide clear explanations, encouragement, reassurance, support and systematic follow-up services. In Botswana patients with CD4 cell counts of less than 200 cells $/ \mathrm{mm}^{3}$, and those with recurrent infections, AIDS-defining illnesses and/or tumours are started on ART (Anabwani \& Jimbo 2005:4-5).

Adherence to prescribed medications is difficult for any chronic condition, but lifelong adherence to ART poses unique challenges. Adherence to ART is critical to obtain maximum and durable decreased viral loads, prevention of viral resistance to $\mathrm{ART}$, reduced destruction of CD4 cells, promotion of immune reconstruction through increased $\mathrm{CD} 4$ cell counts, and slowing down the progression of AIDS-defining illnesses. A study conducted in the United States of America (USA) reported that no opportunistic infections or deaths occurred among patients with at least a 95\% ART adherence rate (Chesney 2000:S171). However, even adherence rates of $80 \%-90 \%$ have been associated with failures to achieve viral suppression. At least a $95 \%$ adherence rate is required to prevent a rebound of plasma viraemia, the development of multi-drug resistance and progression to AIDS (Weiser et al. 2003:282).

\section{Significance of the study}

Providing free ART to the citizens of Botswana might have a limited impact on the development of the HIV/AIDS epidemic in this country, unless ART adherence rates of at least $95 \%$ are sustained. This study attempted to identify the perceptions of nurses (providing ART services) about factors influencing patients' ART adherence levels negatively or positively. Addressing these identified factors could help to increase the ART adherence rates and enhance the impact of ART on many patients' quality of life in Botswana, prevent the development and spread of ART-resistant HIV strains, and enhance health outcomes in this country.

\section{Definition of key concepts}

'Adherence' is defined as the extent to which a client's behaviour coincides with the prescribed health care regimen determined through a shared decision making process between the client and the health care provider (Jani et al. 2002:84). In this study adherence implied that the patients did not miss clinic appointments and took the correct doses of the ARV drugs at the right times and adhered to prescribed food restrictions, according to the patients' reports.

'ARVs (anti-retroviral drugs)' do not cure HIV/AIDS but suppress the replication of HIV to levels undetectable in the blood and also help to increase the number of CD4 cells in the blood (Ward \& Kim 1999:68-69). For the purposes of this study both CD4 cell and viral load counts were done to estimate the person's reaction to ARVs.

'ART (anti-retroviral therapy)' refers to the ARV doses, frequencies and food restrictions prescribed for individual patients. In Botswana patients commence using ART if their CD4 counts are below 200 cells $/ \mathrm{mm}^{3}$ or if they have AIDSdefining illnesses such as wasting syndrome, recurrent severe bacterial infections, encephalopathy or tumours (Anabwani \& Jimbo 2005:5).

'Health service-related factors' in this study refer to aspects of the ART health services which could influence patients' ART adherence such as the accessibility of the ART clinics, availability of ARVs, waiting times at clinics, the availability of laboratory tests, the (in)ability to follow-up defaulters, language barriers, collaboration with traditional healers, nurses' attitudes to patients and the quality of health education provided.
'HIV / AIDS' refers (as used in this study) to a disease progression continuum from testing HIV positive to having AIDS defining illnesses such as pneumocystic carcinii, recurrent infections, pneumonia and signs of 'wasting syndrome'. HIV belongs to a group of retroviruses, a subgroup of lentoviruses implying that these viruses replicate slowly, while they destroy the victim's CD4 lymphocytes making him/her susceptible to opportunistic infections (Ward \& Kim 1999:50-51). HIV is the causative organism of acquired immunodeficiency syndrome (AIDS).

'Patient-related factors' in this study refer to patients' characteristics which could influence their adherence levels to ART negatively, such as their education levels, socio-economic and employment status, non-disclosure and/or non-acceptance of their HIV positive status, alcohol consumption, the severity of the patient's illness, cultural beliefs and ARVs' side-effects experienced by patients.

\section{RESEARCH PROBLEM, PURPOSE AND OBJECTIVES}

In spite of free ARVs, patients do not necessarily adhere to their ART regimens. Non-adherence to ART could result in ARTresistant strains of HIV, implying poorer treatment outcomes with vastly more expensive ARVs and with more side-effects than the initial ART regimens. Thus, ART adherence is beneficial to individual patients, their communities and the country as a whole. The research problem was thus to identify factors, according to nurses' perceptions, that influence Botswana's patients' ART adherence levels positively or negatively.

The purpose of this study was to identify nurses' perceptions about Botswana patients' ART adherence and to identify nurses' perceptions about factors that can influence these patients' ART adherence levels positively or negatively. The research question was: 'According to nurses' perceptions, what factors influence patients' adherence to ART positively or negatively?'.

\section{RESEARCH DESIGN AND METHODS}

An exploratory, descriptive qualitative study was conducted to identify nurses' perceptions about factors promoting and hindering ART patients' adherence to their treatment regimens in Botswana. The study was explorative because no previous studies in this field could be traced and descriptive because the aim was to describe the nurses' perceptions about patients' adherence. A qualitative approach was adopted in an effort to obtain narratives (Polit \& Beck 2006:508) about nurses' perceptions pertaining to patients' ART adherence levels.

\section{Population and sample}

The population of interest for this study comprised all the registered nurses providing ART services at 32 sites in Botswana where patients could obtain free ARVs during 2007. However, due to time and financial constraints not all these sites could participate in this study. The name of every site was written on a piece of paper and placed in a bowl. An independent person drew one slip of paper, wrote down its name, replaced it in the bowl and drew out the next piece of paper until four different sites' names had been selected. In this way random selection with replacement was done. The target population for this study thus comprised all the registered nurses providing ART services at the four selected sites. All registered nurses working at the four sites for at least one year and who were willing to consent to participate in the study comprised the purposive sample for this study because they were assumed to be knowledgeable about factors influencing ART patients' adherence levels. At the four randomly selected sites, 24 registered nurses provided ART services. However, some of them were on leave, attended courses or performed night duty shifts at the local hospitals when their clinics were visited. 16 registered nurses $(66.7 \%$ out of the population of 24) who were available for interviews on the days when the first author visited a specific site comprised 
TABLE 1

Measures taken to ensure trustworthiness

\begin{tabular}{|c|c|c|}
\hline & CRITERIA & APPLICABILITY \\
\hline STRATEGY & Prolonged engagement & Interviewer had established rapport with nurses during a previous research project. \\
\hline \multirow[t]{4}{*}{ CREDIBILITY } & Persistent observation & Questions were rephrased when necessary and rigorous probing was done to obtain in-depth data. \\
\hline & $\begin{array}{l}\text { External checks: } \\
\text { Peer debriefing } \\
\text { Member checking }\end{array}$ & $\begin{array}{l}\text { Two nurse researchers approved the methodology. Audio-tape recordings were played back to each participant for them to } \\
\text { double-check their responses. The preliminary findings were discussed with the participants. }\end{array}$ \\
\hline & Triangulation of data & Semi-structured interviews were audio-taped, transcribed verbatim and correlated with field notes and recorded observations. \\
\hline & Researchers' credibility & All the researchers had extensive experience of qualitative research. \\
\hline DEPENDABILITY & $\begin{array}{l}\text { Inquiry audit } \\
\text { Code-recode procedure }\end{array}$ & $\begin{array}{l}\text { Research methodology was fully described to two external experts. } \\
\text { Consensus approach among the three authors. }\end{array}$ \\
\hline CONFIRMABILITY & Audit trail & Record keeping (field notes, interview transcripts, process notes, data reduction and analysis products and final reports). \\
\hline TRANSFERABILITY & Sample & $\begin{array}{l}\text { Purposive sampling was used to enable only registered nurses experienced in providing ART services to participate in the } \\
\text { semi-structured interviews. }\end{array}$ \\
\hline
\end{tabular}

the convenience purposive sample for the study. In qualitative research, data collection (interviews) ceases when no new information is obtained from further interviewees. This is known as data saturation (LoBiondo-Wood \& Haber 1998:218). After the eleventh interview, the interviewer found that interviewees repeated the same information that had been provided during previous interviews. However, as permission had been granted to collect data from four ART sites in Botswana, the interviews continued until all 16 nurses had participated.

\section{Research instrument}

Semi-structured interviews were conducted with 16 nurses providing ART services at four randomly selected ART sites in Botswana. Semi-structured interviews were used because the researchers had a list of topics or broad questions, derived from literature and from previously conducted structured interviews with ART patients at these sites, which had to be addressed during interviews with the nurses (Polit \& Beck 2006:291).

The first section of the interview schedule contained structured questions seeking demographic information about the nurses' gender, ages, qualifications, years of service at the specific site and HIV/AIDS training. Structured questions were also asked about the clinic hours, the average number of patients failing to collect their ARVs from the clinic on a monthly basis, patients' estimated waiting times at the clinic and the availability of ARVs. These structured questions were asked first so that the interviewee could be put at ease. The semi-structured questions concerned:

- Steps taken when the pharmacy ran out of ARVs

- Reasons why patients missed their monthly appointments; nurses' actions in these cases; nurses' actions if patients turned up one month after their appointment dates

- Contacting defaulting patients and follow-up procedures

- The information given to patients about their CD4 cell and viral load counts and about ARVs (and the recording of such information on patients' files)

- Patients' use of traditional healers/medicines

- Recommendations for enhancing ART adherence at the specific clinic.

\section{Data collection procedure}

The first author made appointments with every registered nurse for a specific date and time to conduct the interview. Each interview was conducted in a private room and tape-recorded, subsequent to obtaining specific permission from every interviewee to do so. The interviewer also recorded observations and made field notes. Probing was done rigorously to cover every aspect in as much depth as possible.

\section{Trustworthiness}

Trustworthiness refers to the confidence qualitative researchers have in their data. This was assessed using the criteria of
TABLE 2

Service- and patient-related factors influencing Botswana's patients' ART adherence levels

\begin{tabular}{ll}
\hline SERVICE-RELATED FACTORS & PATIENT-RELATED FACTORS \\
\hline Accessibility of the ART clinics & Literacy levels \\
Maintenance of ART stocks & Financial situations \\
CD4 and viral load results & Non-disclosure of HIV positive status \\
Health education provided & Side effects of ARVs \\
Nurses' inability to follow-up defaulting & Improvement in clinical condition \\
ART patients & Using traditional medicines/healers' \\
Nurses' counselling skills and attitudes & services \\
Language barriers & \\
Collaboration with traditional healers & \\
\hline
\end{tabular}

credibility, transferability, dependability and conformability (Polit \& Beck 2006:511) as summarised in Table 1.

\section{Data analysis}

The answers obtained in response to the closed-ended questions were analysed quantitatively. Tesch's method of open coding (Cresswell 2003:192-193) was used to analyse the qualitative data obtained in response to the semi-structured questions. Despite using semi-structured interviews, open-coding was used to analyse the nurses' responses to the open-ended questions. Open coding can be defined as examining ... 'data carefully line by line, broken down into discrete parts, and compared for similarities and differences' (Lobiondo-Wood \& Haber 1998:228). Initially the transcripts of the interviews were read and reread and all the audiotapes were listened to repeatedly while writing down any ideas that came to mind. Tape recordings of all 16 interviews were transcribed verbatim to facilitate the qualitative data analysis process. One interview was selected, and all thoughts were written in the margins, making lists of topics and clustering these into major themes, unique themes and leftover topics repeatedly. Finally the related data materials of each category were assembled in one place and interrelations among different categories were identified and examined by the three authors until consensus about the themes and categories had been reached. As a result of this repeated process of analysis, two major data categories, namely patientrelated and service-related factors were the major groups of factors influencing patients' ART adherence levels, according to the nurses' perceptions.

\section{Ethical considerations}

Permission was granted by the Health Research Unit of Botswana's Ministry of Health and the four participating health care facilities' managers as well as from the Research and Ethics Committee of the Department of Health Studies, University of South Africa. Informed consent was obtained from every 
participant prior to each interview. The interviewees were assured that anonymity and confidentiality would be maintained No names were recorded, and the interviews were recorded on the audio tape recorder according to number, ranging from 1-16. The research report would not identify any person, institution or specific ART site.

Each interview was conducted at a predetermined time in a private room without any interruptions. All participants were assured that participation was voluntary, their personal opinions and experiences were valued implying that there were no right and no wrong answers, and that they could withdraw at any stage without suffering any ill effect whatsoever. As only a semistructured interview was conducted with each participant, no harm was inflicted. However, all participants could contact the interviewer should they wish to do so. Participants were assured that the audiotapes of the interviews would be stored in a locked cabinet and that both these tapes and the typed transcriptions would be destroyed subsequent to the acceptance of the research report. If the participants desired research reports, these could be supplied subsequent to the acceptance of the research report.

\section{RESEARCH FINDINGS}

The data obtained in response to the closed-ended questions will be presented quantitatively. Thereafter the findings, obtained in response to the semi-structured questions, will be discussed according to the themes and the categories derived from the data, as summarised in Table 2. Appropriate direct quotes support the results, where relevant.

\section{Biographic Information}

The majority $(n=15 ; 93.8 \%)$ of the participants were females; all $(\mathrm{n}=16 ; 100.0 \%)$ were registered nurses and only $1(6.3 \%)$ was an ARV nurse specialist. All 16 (100\%) participants had been working at the ART sites for more than one year and had completed HIV/AIDS training and 10 (62.6\%) nurses had undergone medication adherence training, while $6(37.5 \%)$ had not done so. This HIV / AIDS training for nurses, pharmacists and social workers, focuses on potential barriers to ART adherence within the Botswana context (Miles et al. 2007:556). All nurses indicated that increasing numbers of ART patients failed to keep their clinic appointments and renew their ART supplies every month. The estimated number of patients defaulting on a monthly basis ranged from 20 to 60 per clinic.

\section{Factors influencing patients' ART adherence levels}

The major categories, classified from responses to the semistructured interviews, were service-related and patientrelated factors influencing patients' ART adherence levels, as summarised in Table 2

\section{Service-related factors influencing patients' ART adherence levels}

As indicated in Table 2, service-related factors influencing patients' adherence levels to ART include the accessibility of ART clinics, availability of ARVs, CD4 cell and viral load results, health education provided, nurses' inability to followup defaulters, nurses' counselling skills and attitudes, language barriers and collaboration with traditional healers.

\section{Accessibility of ART clinics}

Many patients encountered difficulties in accessing ART clinics because some had to travel up to 200 kilometres to reach the nearest clinic. Other studies reported similar findings, that having to travel long distances to ART clinics had negative effects on ART adherence (Alcorn 2004:1; Poppa 2002:1; Weiser et al. 2003:285). The clinic hours were from 07:30 until 16:30, Mondays to Fridays. The nurses reportedly sometimes worked until 18:00 to accommodate large numbers of patients. During weekends and public holidays, the ART clinics were closed, making it difficult for working patients to collect their ARVs. Kgatlwane et al. (2006:102) reported that some employers in Botswana would not give their employees time off to attend ART clinics.

Some patients arrived at the ART sites before 05:00 to ensure their places near the front of the queue. Some Botswana citizens have more than one home and spend certain parts of the year at cattle posts tending their livestock away from their residential homes, making it even more difficult to reach the ART sites. The waiting times at the clinics reportedly ranged from 20 minutes to eight hours, a finding supported by Kgatlwane et al.'s (2006:110) research in Botswana.

Aidsmap (2007:7) reports that nurses can identify and refer toxicities and treatment failures while treating many patients themselves. Similar experiences were reported by the participants in this study. At two sites patients' waiting times had reportedly been reduced because specially trained nurses consulted adult patients who had been on HAART for at least six months, and who had stable CD4 cell counts of more than $200 \mathrm{~mm}^{3}$ and undetectable viral loads. The participating nurses commented:

'Some patients say they cannot wait in line all day because they lose their business and livestock. This makes them miss clinic appointments.'

'Sometimes there is one bus that comes once a day from the rural areas and if there is no bus, patients miss their appointments.'

'Most patients from the remote areas are brought by the ambulances or police vehicles and when these vehicles are not there, the patients don't come. There are some patients who come from $200 \mathrm{~km}$... travelling is a problem especially when transport is not that reliable.

Having to travel long distances to clinics, lack of reliable transport, clinic hours, long waiting times at clinics and the inability to attend clinics during working hours could influence patients' ART adherence rates negatively.

\section{ARV supplies}

Three sites had reportedly never run out of ARV drugs, while this had happened at one site once only during the preceding month. This indicates that most patients could get ARVs at specific visits. The nurses stated that they had procedures in place to obtain supplies within 3 to 4 days, despite transport problems. However, ARVs were hardly ever depleted because adequate supplies were maintained at the sites. The unavailability of ARVs should thus not influence patients' ART adherence rates negatively in Botswana. Stewart et al. (2004:35) agreed that ART shortages were unusual.

\section{CD4 and viral load results}

Patients with CD4 cell counts of between $200-300 \mathrm{~mm}^{3}$ were checked every three months and those with higher CD4 cell counts every six months. The participating nurses indicated that this depended on the presence of AIDS defining illnesses. Irrespective of the patients' CD4 cell counts those who had AIDS symptoms commenced using ARVs. Patients with stable conditions had their viral load counts checked every six months but those with problems were checked every three months. This is in accordance with Botswana's guidelines on ART (Anabwani \& Jimbo 2005:3-4). However, the patients reportedly had to wait for more than a month to get their viral load results - at one site patients reportedly had to wait for three to six months. A participant explained:

'In this site, the viral load now has taken more than three months because when the results came from the referral laboratory after two months, we queried them. All the viral load results were extremely high, more than 1000 copies per ml of blood for all patients - even those patients that we know they are stable and are adhering to their ART regimens very well. So we had to re-send those results back to be re-checked. At the moment, we have not yet received the feedback.' 
Delays at two other sites occurred because they did not have the necessary equipment to do viral load estimates and patients' blood specimens had to be sent to laboratories at referral hospitals while the last site had the equipment but no reagents to do the test at the site.

Keeping record of every patient's laboratory results was problematic at one site, as explained by a nurse:

'There is a problem with data handling. We do not have a data clerk. We have requested for one but management does not see this as a priority. The information is not up to date. Doctors and laboratory personnel do not use computers so it is hard for nurses to check the results. Some patients have virological failure and we are not able to notice that easily.'

These findings are similar to those reported by Stewart et al. maintaining that

... in Botswana the implementation of a new health information system necessitates the training of more than $95 \%$ of health workers in basic computer skills. The longstanding familiarity with, and dependence on paper based systems, needs to be challenged. The lack of software packages appropriate for understaffed, high workload, high volume settings with low levels of computer literacy and the need to ensure that each patient would be uniquely identifiable regardless of the site at which he or she presented were further identified.

(Stewart et al. 2004:3)

These authors (Stewart et al. 2004:37) also emphasise that a weak patient information system impacts negatively on the ongoing assessment and treatment of patients.

\section{Health education provided}

According to Malta et al. (2005:1425), patients who receive comprehensive information about their ART regimens, who have access to culturally sensitive health services and who have open dialogue with their health care providers are more likely to be adherent to both ART regimens and clinical follow-up visits. According to the participants in this study, doctors and nurses conveyed patients' blood test results to them. The nurses used simple Setswana language such as 'soldiers of the body' or 'Botswana Defence Force' for CD4 cells. Patients with CD4 cell counts of less than $200 \mathrm{~mm}^{3}$ were informed that their immunity was low and those with CD4 cell counts above $500 \mathrm{~mm}^{3}$ were told that their immunity was doing well; in Setswana viral load was explained as 'bokete jwa mogare' (meaning the level/count of virus in the blood). Health education provided to patients included the following aspects:

'We tell them that HIV destroys the CD4 cells and once these cells are low, one is prone to many diseases and then the individual progresses to AIDS.'

'For those who are not yet on HAART, we say to them that once their CD4 cell counts are below $200 \mathrm{~mm}^{3}$, they are eligible to start HAART and for those on HAART we tell them that if they do not comply with the treatment their CD4 counts will go down and they will get sick.'

'We tell them that the virus lives in the blood... viral load is the most important indicator to check if $A R V$ s are working and if it has been undetectable but suddenly goes up again then that means there is something wrong.'

'We also say ...that once they start treatment, the CD4 cells will increase and the virus will go to sleep. That is, if they are strictly adhering to their treatment regimen that they will live well like anybody else."

According to the nurses, ART information was mostly supplied to the patients by doctors during consultations, nurses during adherence counselling and pharmacists when dispensing the ARVs. Reportedly the nurses informed the patients about ARVs in different ways.
We explain to the patients that $A R V$ s are not curative treatments but that they only suppress the virus... ARVs need commitment ... ARVs are lifelong treatments and must be taken the same time every day.'

'We inform them about drug to drug interaction and that they should avoid combination with traditional medicines or alcohol.'

'We counsel them that it is very important to have regular check ups of CD4 cell and viral load counts while on ART.'

'We explain that ARVs should not be shared with anybody.'

'Patients should know that ARVs can cause complications with liver functions. Patients should know the consequences of nonadherence to ARVs, for example, virological failure.'

In addition to CD4 cell and viral load counts and ARVs, the nurses taught ART patients about nutrition, behavioural change (safer sex, condom use) and re-infection possibilities, and about Isoniazid Preventive Therapy (IPT) for tuberculosis. Although laboratory results were recorded in patients' files, health education details were not recorded. These aspects were ticked off on a check-list including items related to the patient's knowledge about HIV, HAART and adherence. These statements were graded as 'good', 'limited'or 'poor'. Patients' living conditions, nutritional status, employment status and substance abuse were rated as 'adequate' or 'difficult - needs referral to social worker'. One participant commented:

'The information we give to our patients is not written in detail, there is a small form on adherence assessment but it is not very specific, we cannot comment on the form, we just tick.'

Large numbers of patients and inadequate numbers of nurses posed challenges:

'We have too many patients and nowadays patients do not like to wait for very long. There is not enough time to explain the information and assess if the patients understood the details.

Nurses reportedly also taught patients about the dangers of alcohol consumption, contributing to ART non-adherence and to non-utilisation of condoms. The health education provided by the nurses should enhance patients' capacities to adhere to their ART regimens. These findings are supported by Malta et al. (2005:1425), as well as by Stewart et al. (2004:43) who emphasise that relevant information is essential for safe and effective ART.

Nurses' inability to follow-up defaulting ART patients Some nurses from three sites said that they followed up defaulting patients while at the fourth site all the nurses reported that they did not follow-up defaulters. Follow-up (home) visits were only conducted within the clinics' vicinities, because the ART clinics did not provide transport to follow up patients who lived far from clinics. Fong et al. (2003:134-135) reported that patients with irregular follow-up visits and histories of missing clinic appointments were less likely to adhere to their ART regimens than those who attended clinics regularly. Follow-up visits could improve patients' clinic attendances and thus their virological, immunological and clinical ART outcomes (Malta et al. 2005:1425).

The nurses could only phone patients who had landline phones and were not allowed to call patients on cell phones (due to expenses). However, most patients only had cell phones and could thus not be reached telephonically. Sometimes clinic nurses called the primary health care (PHC) clinic closest to the defaulting patients' homes. Nurses working at the PHC clinics were requested to trace these patients, but could not always provide feedback to the ART clinics. At three sites family welfare educators assisted in tracing defaulting patients living near the clinics. Patients who had moved to the cattle posts or fields (masimo) could not be reached.

At two sites the ART clinic nurses had to work night shifts in the local hospitals. One participant commented: 
'Nurses have to do night duty in the general wards of the hospital and we cannot follow up our patients since there is always short staff in the clinic. There are piles of cards of patients that have not come for follow up but we have no time to go get them. People are defaulting and we are not able to follow them. The numbers are increasing and the default rate is also increasing. We are under pressure.'

The nurses' reported inability to conduct follow-up visits, and even to contact defaulters telephonically could impact negatively on the patients' ART adherence rates.

\section{Nurses' counselling skills and attitudes}

Reportedly not all nurses were skilled in counselling patients. This might be due to a lack of training as $37.5 \% \quad(n=6)$ of the participating nurses had not yet undergone adherence counselling training and $68.8 \%(\mathrm{n}=11)$ had not yet completed the ART training programme. Stewart et al. warn that

'... health care workers at all levels require clear and relevant information to carry out their work and to educate their colleagues and the public about ARVs. Ignorance or incorrect information about HIV/AIDS can operate as barriers to diagnosis and effective care of HIV/AIDS.

(Stewart et al. 2004:43)

Some nurses participating in the current study indicated that some patients might have missed their follow-up clinic appointments because the nurses did not always portray positive attitudes towards ART patients,

'...making these patients afraid of us.'

'Because of the workload, it is hard and difficult for nurses to keep their temper.'

'Patients come to the clinic in their own time and some of us nurses don't like that because there is no time to rest.'

These findings that nurses' lack of counselling skills and inappropriate attitudes could affect adherence rates negatively concur with those reported by Modiba et al. (2002:4) as well as Reis et al. (2005:743), indicating that positive and accepting health care workers' attitudes helped patients to enhance their ART adherence rates.

\section{Language barriers}

At two sites the nurses could not converse in the local languages of the patients. Kgatlwane et al. (2006:121) also observed language barriers between health workers and ART patients to be a problem in Botswana. Language barriers might have impaired the ART patients' understanding of ARVs as well as CD4 and viral load information, potentially affecting ART adherence, as indicated by the following statement:

'We have language barriers between the nurses, pharmacy personnel and our clients. Here people speak Kalanga, they don't speak Setswana. Most of the nurses don't speak Kalanga and most of the pharmacy personnel are foreigners who speak neither Setswana nor Kalanga. So the patients are disadvantaged when they are given information about their ARV drugs. Some of the messages are distorted because we ask the cleaners to translate.'

Cultural and language barriers could negatively affect patients' ART adherence levels (Kgatlwane et al. 2006:121; Marazzi et al. 2006:40).

\section{Collaboration with traditional healers}

Some nurses from one site said they collaborated with traditional healers while others from the same site denied this to be the case. All participants at another site said they collaborated with traditional healers in their area, while nurses from the remaining two sites reported no such collaboration. The nurses explained their lack of collaboration with traditional healers as follows:

"Traditional practice is like a taboo in this culture. People do it in secret and they consult these people during the night... to many people it is a secret and traditional healers are not willing to deal with health workers.'
'Traditional healers, especially those faith healers, are telling people to stop taking ART. Do you think they would like to collaborate with us?

'We don't have time for collaboration with traditional healers. We are very busy...

'This hospital is a Christian institution and they don't believe in traditional healing, so maybe because of that ... there is no collaboration ... I am not sure.'

Other research reports also reported that a lack of collaboration between ART services and traditional healers in African countries could influence ART adherence rates negatively (De Korte et al. 2004:12; UNAIDS 2000:10).

\section{Patient-related factors influencing ART adherence}

As indicated in Table 2, patient-related factors influencing ART adherence rates include patients' literacy levels, financial situations, non-disclosure of their HIV positive status, ARVs' side-effects, improvement in clinical condition and the use of traditional medicines/healers' services.

\section{Literacy levels}

Most ART patients were reportedly illiterate and could not read instructions regarding clinic appointments, ART information, CD4 cell counts and viral load information. Many ART patients reportedly misunderstood their ART instructions due to illiteracy. These potential misunderstandings were aggravated by the nurses' inability to communicate with patients in the local languages. One nurse explained the situation:

Some patients cannot read the instructions. They don't understand anything at all. Patients have problems to understand what we say because they don't know how to read and write. This is our big problem in the provision of these ARVs... It's good that the government introduced ARVs, but if they are not taken well, this will be a disaster.'

Low literacy levels impact negatively on ART patients' comprehension and thus also on their adherence levels, a finding supported by Kalichman, Ramachandran and Catz (1999:270) and Malta et al. (2005:1425).

\section{Financial situation}

Botswana provides ART free of charge to its citizens, but patients have to pay for transport to and from the clinics. Many ART patients lived in remote rural areas without public transport. If there was no transport, or if they had no money, they failed to turn up for their appointments. Some patients had difficulties to get time off from their jobs to attend ART clinics, especially if they had to wait $4-8$ hours at ART clinics. Some patients could not leave their livestock in distant rural areas of Botswana and attend ART clinics.

Kgatlwane et al. (2006:127) and Sherriff (2003:1) agreed that lack of transport, the cost of transport and the possibility of losing a day's income impacted negatively on Botswana's ART patients' clinic attendance, and thus also on their ART adherence. Economic issues do affect ART adherence rates even if the ARVs are supplied free of charge.

\section{Non-disclosure of HIV positive status}

Some patients did not reveal their HIV positive status to their spouses or relatives, making it difficult to attend clinics and take their ART regularly. One nurse explained this situation as follows:

'Some patients are not adhering because they don't tell their family members. So they have to sneak out to come to the clinic, so sometimes they miss clinic appointments because they don't want other people to know that they are taking $A R V$ s... women... have not disclosed to their spouses because of fear of being abandoned.'

Stone (2001:868) also maintains that ART adherence is influenced negatively by patients who fail to disclose their HIV+ve status to 
their significant others and/or deny that they are HIV positive. Knowing about someone with HIV / AIDSis reportedly associated with increased tolerance towards HIV positive persons (Muula \& Mfutso-Bengo 2005:289).

\section{Side-effects of ARVs}

Only twonurses reported that patients missed clinic appointments and/or failed to take their ARVs because of side-effects. As sideeffects develop slowly and often appear after extended periods of time on ARVs (Meldrum et al. 2004:108) these occurrences could become more frequent in future. However, at the time of the data collection, side-effects were reportedly not a serious consideration influencing ART patients' adherence levels.

\section{Improvement in clinical condition}

Some patients reportedly adhere to ART while sick but when they get better, they forget to take their ART on time. This finding is supported by Tsasis (2001:111) and by Malta et al. (2005:1424). The nurses assessed the ART patients for adherence constraints, patients who defaulted were re-started on ART and referred to social workers for further management.

\section{Using traditional healers' services/medications}

The nurses reported that some ART patients used traditional healers' services, and that the nurses informed the ART patients about the dangers of combining ART and traditional medicines. One participant commented:

'We have had patients who came and vomited in our department because of overdose of traditional medicines but they deny using them.

Some patients stopped using traditional medicines after being initiated on ART, but others discontinued ART if advised to do so by a traditional healer:

At the initiation of ARVs, most of the patients are using traditional medicines but then they are counselled and once they are counselled they decide to stop. But there are others who prefer to finish the course given by traditional healers then they start $A R V$. Others just take them topically not orally.

'Some of our clients still take traditional medicines and also some consult faith healers who tell them to stop taking ARV medications. These faith healers tell the patients that only God will heal them. There are some patients who are forced by the elders in the village to stop ARVs and take traditional medicines especially if their spouse dies while on ART.'

'Some patients say they were told by traditional healers to take traditional medicines and stop taking ART.

'There are those patients who believe that traditional medicines boost the immune system.'

Following traditional healers' instructions to take traditional remedies and/or to discontinue taking ART will influence ART patients' adherence levels negatively, as indicated by De Korte et al. (2004:11) and Weiser et al. (2003:285).

\section{RECOMMENDATIONS}

High levels of ART adherence are essential to avoid the development of resistance to ARVs, virological failure and increased mortality rates (Marazzi et al. 2006:34). The sixteen nurses who participated in the interviews suggested that ART adherence rates in Botswana could be enhanced if:

- ART clinics' nurses had transport to do follow-up home visits to defaulters

- Mobile clinics could provide ART services in distant places

- Nurses could contact ART patients on their cell phones

- Adherence counsellors could be appointed in every village

- ART clinic nurses were no longer required to work night duty shifts at the local hospitals

- Adherent ART patients could be trained to be peer counsellors for other patients - in their local languages - saving time for nurses, doctors and pharmacists while enhancing the ART patients' comprehension of HIV/AIDS, ART, CD4 cell and viral load counts in order to improve their understanding of lifelong adherence to ART.

Other recommendations, based on the results of this study, include that:

- CD4 and viral load test results should become available as soon as possible. Researchers should be encouraged to produce a CD4 test kit equivalent to that used to determine blood glucose or haemoglobin levels.

- Health education provided to patients should be recorded on their charts.

- Nurses should continue to improve their counselling skills and maintain supportive attitudes to all ART patients.

- ART patients should receive transport vouchers to enable them to travel to clinics even if they do not have money to pay for transport.

- ART patients should be encouraged to disclose their HIV positive status to their significant others to facilitate their adherence to ART.

- Special health education should be provided to patients whose clinical conditions improve to encourage them to continue taking ART every day for the rest of their lives.

- Possible collaborations with traditional healers should be investigated. Traditional remedies should be analysed pharmacologically so that health care workers can tell ART patients which remedies to avoid in order to avoid the risk of drug-drug interactions producing hepato-toxicity. Forbidding the use of all traditional medicines for the rest of the ART patient's life is unlikely to have the desired results, because in Botswana people believe in traditional healers (Brink 2003:44; De Korte et al. 2004:11; Talbot et al. 2002:282 \& Weiser et al. 2003:283).

Service-related and patient-related factors were identified which, if addressed effectively, could significantly enhance patients' ART adherence levels. This would have multiplier effects contributing to patients' and their families' enhanced quality of life, extended economic earning capacities of patients, reduced numbers of opportunistic infections with reduced hospitalisation costs, delayed onset of AIDS-defining illnesses and curbing the spread of ARV-resistant strains of HIV throughout communities or even the country. Effective ART programmes demand more than the mere provision of free ARVs to patients because an effective health care system, laboratory services, communication systems and specially trained nurses, doctors, pharmacists and health educators are indispensable to the successful implementation of an ARV programme in any country.

\section{CONCLUSION}

The risk that large numbers of Botswana citizens could contract HIV strains resistant to ART increases as the number of ART patients who fail to maintain at least a $95 \%$ adherence level continues to increase. This study's results indicate that two major categories of service-related and patient-related factors impacted on ART patients' adherence levels.

Merely supplying ARVs free of charge, and having the ARV supplies at clinics, did not enable ART patients at the four participating ART sites in Botswana to adhere to their treatment regimens, according to the participating nurses' responses. Many patients could not reach the ART clinics due to lack of transport and lack of money; some patients could not wait up to eight hours at ART clinics every month, risking losing their jobs. People tending their fields or livestock at cattle posts could not access ART clinics. CD4 and viral load test results took too long to become known. Although nurses provided health education to ART patients, these activities were not fully recorded on the patients' charts. The nurses were unable to trace defaulters because they did not have transport to travel to patients' homes, could only use landline phones while most patients had only cellular phones, and the nurses had to work night duty shifts 
at the local hospitals. Some nurses lacked counselling skills and did not support the ART patients. Furthermore the nurses could not communicate with all patients in their local languages and did not collaborate effectively with traditional healers in their areas. Patient-related factors that impacted negatively on patients' adherence levels included low literacy levels, financial constraints, non-disclosure of their HIV positive status, patients' improved clinical conditions and the use of traditional healers/ medicines.

\section{REFERENCES}

Aidsmap, 2007, Professional roles and ARV provision: Scaling up treatment and models of service delivery, viewed 3 January 2008, from http://www.aidsmap.com/cms1199940. asp?tyupe $=$ preview .

Alcorn, K., 2004, Is paying for treatment affecting adherence in Africa?, viewed 12 September 2005, from http://www. aidsmap.com/en/news/FO60ECEE-2A1E-489D-819137AA389DO7E3.asp.

Anabwani, G. \& Jimbo, W., 2005, Botswana: Guidelines on antiretroviral treatment, rev. edn., Ministry of Health, Gaborone

Brink, S., 2003, 'Dancing in the dark: New hope for AIDS in Africa', US News \& World Report 135(21), 44-56.

Chesney, M.A., 2000, 'Factors affecting adherence to antiretroviral therapy', Clinical Infectious Diseases 30(2), S171-176.

Cresswell, J.W., 2003, Research design: Qualitative, quantitative and mixed methods approaches, 2nd edn., Sage, London.

De Korte, D., Mazonde, P. \& Darkoh, E., 2004, Introducing ARV therapy in the public sector in Botswana. Perspectives and practices in antiretroviral treatment, viewed 3 June 2005, from http://www.achap.org/downloads/DonaldWHO_ARV_ Botswana.pdf.

Fong, O., Fung, L.Y., Lee, F.K., Yuen, C.Y., Sin, K.P. \& Wong, K.H., 2003, 'Determinants of adherence to highly active antiretroviral therapy (HAART) in Chinese HIV/AIDS patients', British HIV Association HIV Medicine 4(2), 133-138.

Grubb, I., Perriens, J. \& Schwartlander, B., 2003, 'Perspectives and practice in antiretroviral treatment. A public health approach to antiretroviral treatment: Overcoming constraints', viewed 8 June 2005, from http://www.who.int/ hiv/toolkit/arv/media/PublicHealthApproach_E.pdf.

Jani, A.A., Stewart, A., Nolen, R.D. \& Tavel, L., 2002, Medication adherence and patient education in HIV/AIDS, viewed 6 May 2005, from http://www.faetc.org/PDF/Primary Care Guide/08--Medication-Adherence-and-Patient-Education. pdf.

Joint United Nations Program on HIV/AIDS, 2004, Country HIV/AIDS estimates, 2003-Botswana, viewed 7 June 2005, from http://www.unaids.org/en/geographical+area/ by+country/botswana.asp

Kalichman, S.C., Ramachandran, B. \& Catz, S., 1999, 'Adherence to combination antiretroviral therapies in HIV patients of low literacy', Journal of Internal Medicine 14(5), 267-273.

Kgatlwane, J., Ogenyi, R., Ekezie, C., Madaki, H.N., Moyo, S. \& Moroka, T.M., 2006, 'Factors that facilitate or constrain adherence to antiretroviral therapy among adults at four public health facilities in Botswana: A pre-intervention study', viewed 30 November 2007, from http://mednet3. who.int/PRDUC/Book/Botswana Final.pdf.

Lobiondo-Wood, G. \& Haber, J., 1998, Nursing research: Methods, critical appraisal, and utilization, 4th edn., CV Mosby, St Louis.

Malta, M., Peterson, M.L., Clair, S., Freitas, F. \& Bastos, F.I., 2005, 'Adherence to antiretroviral therapy: A qualitative study from Rio de Janeiro, Brazil', Cad Saude Publica 21(5), 14241432

Marazzi, M.C., Bartolo, M., Gialloretti, L.E., Germano, P., Guidotti, G., Liotta, G., Magnano San Lio, M., Mancinelli, S., Modolo, M.A., Narciso, P., Perno, D.F., Scarcell, P., Tintisona, G. \& Palombi, L., 2006, 'Improving adherence to highly active antiretroviral therapy in Africa: The DREAM programme in Mozambique', Health Education Research 21(1), 34-42.

Meldrum, J., Prabhu, V.J., Orrell, C., Martin, D., Wilson, D., Regensburg, L., Barigye, H., Rabkin, M. \& Nyazema, N., 2004, 'Talking about side effects', viewed 3 January 2008, from http://www.aidsmap.com/en/docs/58BDDA34-74CF4C27-842C-65E677A8FD47.asp

Miles, K., Clutterbuck, D.J., Seitio, O., Sebego, M. \& Riley, A., 2007, 'Antiretroviral treatment roll-out in a resource-constrained setting: Capitalising on nursing resources in Botswana', Bulletin of the World Health Organization 85(7), 555-560.

Modiba, P., Schneider, H., Weiner, R., Blaauw, D., Gibson, L. Zondi, T., Kunene, X. \& Brown, K., 2002, 'The integration of HIV/AIDS care and support into primary health care in Gauteng Province', viewed 25 January 2006, from http:// www.hst.org.za/uploads/files/hiv gaut.pdf.

Muula, A.S. \& Mfutos-Bengo, J.M., 2005, 'When is public disclosure of HIV seropositivity acceptable?', Nursing Ethics 12(3), 288-295.

National AIDS Coordinating Agency and Central Statistics Office, 2004, Botswana impact survey II: Technical Report 1-241, NACA \& CSO, Gaborone.

Polit, D.F. \& Beck, C.T., 2006, Essentials of nursing research: Methods, appraisal and utilization, 6th edn., Lippincott Williams \& Wilkins, Philadelphia.

Poppa, A., 2002, Antiretroviral adherence in resource-poor settings: Challenging the voices of doom, viewed 16 October 2005, from http://www.aidsmap.com/en/news/BD558D6-2090-40A5BA57.

Reiss, C., Heisler, M., Amowitz, L.L., Moreland, R.S., Mafeni, J.O., Anyamele, C. \& Lacopino, V., 2005, 'Discriminatory attitudes and practices by health workers toward patients with HIV/AIDS in Nigeria', PloS Medicine 2(8), 743-752.

Sherriff, L., 2003, 'Cost of care shown to be primary barrier to adherence in African study', viewed 12 September 2005, from http://www.aidsmap.com/en/news/3E8B197B-393946E6-BF00-OCDE13F722D5.asp.

Stewart, R., Paradath, A. \& Bamford, L., 2004, Providing antiretroviral treatment in Southern Africa: A literature review, Health Systems Trust, Durban.

Stone, V., 2001, 'Strategies for optimising adherence to highly active antiretroviral therapy: Lessons from research and clinical practice', Clinical Infectious Diseases 33(6), 865-872.

Talbot, E.A., El-Halabi, S., Manchandra, R., Mwansa, R.A. \& Wells, C.D., 2002, 'Knowledge, attitudes, and beliefs about directly-administered antiretroviral therapy among tuberculosis patients, Botswana', International Journal of STDs \& AIDS 15(4), 282-283.

Tsasis, P., 2001, 'Adherence assessment to highly active antiretroviral therapy', AIDS Patient Care and STDs 15(3), 109-115.

Ward, D.E. \& Kim, M., 1999, 'The complete guide to understanding HIV and AIDS', The AmFAR AIDS Handbook, Norton, New York.

Weiser, S., Wolfe, W., Bangsberg, D., Thior, I., Gilgert, P., Makhema, J., Kebaabetswe, P., Dickenson, D., Mompati, K., Essex, M. \& Marlink, R., 2003, 'Barriers to antiretroviral adherence for patients living with HIV infection and AIDS in Botswana', Journal of Acquired Immune Deficiency Syndromes 34(3), 281-288.

World Health Organization, 2002, WHO traditional medicine strategy 2002-2003, WHO, Geneva.

World Health Organization, 2003, World Health OrganizationARV toolkit. A public health approach for scaling up antiretroviral (ARV) treatment, viewed 7 June 2005, from http://www. who.int/hiv/toolkit/arv/en/index.jsp. 